\title{
Comparison of Transradial Percutaneous Coronary Intervention in Patients with Stable and Unstable Coronary Artery Disease
}

\author{
Samir Duarte Ibrahim 1 , J. Ribamar Costa $\mathrm{Jr}^{2}$, Rodolfo Staico ${ }^{3}$, Dimytri Alvim Siqueira ${ }^{4}$, Luiz Fernando Tanajura ${ }^{5}$, \\ Ricardo A. Costa ${ }^{6}$, Jackson Rafael Stadler ${ }^{7}$, André Bastos Paixão ${ }^{8}$, Daniel Chamié ${ }^{\text {, Sérgio Braga }}{ }^{10}$, Fausto \\ Feres $^{11}$, Alexandre Abizaid ${ }^{12}$, Amanda G. M. R. Sousa ${ }^{13}$, J. Eduardo Sousa ${ }^{14}$
}

\begin{abstract}
Background: The transradial approach for percutaneous coronary intervention (PCI) is still not widely used in our country. We evaluated the results of transradial PCI performed at a tertiary hospital, which has progressively incorporated this technique to its daily clinical practice. Methods: This is a retrospective study of patients treated from 2007 to 2012 at Instituto Dante Pazzanese de Cardiologia. Clinical, angiographic and procedural profile and in-hospital outcomes of patients with stable and unstable coronary artery disease $(\mathrm{CAD})$ treated with the transradial approach were compared. Results: We included 2,507 patients, of which $72.6 \%$ had stable and $27.4 \%$ had unstable CAD. Patients with stable CAD had a more complex clinical profile, characterized by being older, more frequently females, with a higher incidence of comorbidities. The angiographic and procedural characteristics were not different for most of the variables analyzed. The success rate was high, but higher in the stable CAD group $(94.6 \%$ vs. $92.4 \%$; P $=0.05)$. The incidence of death $(0.2 \%$ vs. $0.3 \% ; \mathrm{P}=0.61)$, periprocedural infarction $(4.7 \%$ vs. $6.6 \% ; \mathrm{P}=0.07)$, stroke $(0.1 \%$ vs. $0.1 \%$; P > 0.99$)$, PCI $(0.1 \%$ vs. $0.3 \% ; \mathrm{P}=0.30)$, coronary artery bypass graft ( 0 vs. $0.4 \% ; \mathrm{P}=0.06)$, major bleeding $(0.2 \%$ vs. $0.6 \% ; \mathrm{P}=0.09)$ or vascular complications $(1 \%$ vs. $0.6 \%$; $\mathrm{P}=0.47)$ was low and did not differ between groups. Conclusions: Transradial PCI has proved to be safe and effective in patients with stable and unstable CAD, treated at a tertiary hospital that has progressively incorporated this technique to its daily practice.
\end{abstract}

\section{RESUMO}

\section{Comparação da Intervenção Coronária Percutânea por Via Radial em Pacientes com Doença Arterial Coronária Estável e Instável}

Introdução: A intervenção coronária percutânea (ICP) por via radial ainda é pouco utilizada em nosso meio. Avaliaram-se aqui os resultados da ICP por via radial, realizada em um hospital terciário, que, progressivamente, tem incorporado tal técnica à prática clínica diária. Métodos: Estudo retrospectivo, de pacientes tratados entre 2007 e 2012, no Instituto Dante Pazzanese de Cardiologia. Compararam-se os perfis clínico, angiográfico e do procedimento e os resultados hospitalares dos pacientes tratados por via radial com doença arterial coronária (DAC) estável e instável. Resultados: Foram incluídos 2.507 pacientes, sendo $72,6 \%$ portadores de DAC estável e $27,4 \%$ de DAC instável. Os pacientes portadores de DAC estável tinham perfil clínico mais complexo, caracterizado por serem mais idosos, mais frequentemente do sexo feminino e com maior incidência de comorbidades. As características angiográficas e do procedimento não mostraram diferenças na maioria das varáveis analisadas. A taxa de sucesso foi elevada, porém maior no grupo DAC estável $(94,6 \%$ vs. $92,4 \% ; \mathrm{P}=0,05)$. A incidência de óbito $(0,2 \%$ vs. $0,3 \% ; P=0,61)$, infarto periprocedimento $(4,7 \%$ vs. $6,6 \% ; \mathrm{P}=0,07)$, acidente vascular cerebral $(0,1 \%$ vs. $0,1 \% ; \mathrm{P}>$ $0,99)$, ICP $(0,1 \%$ vs. $0,3 \% ; \mathrm{P}=0,30)$, cirurgia de revascularização miocárdica ( 0 vs. $0,4 \% ; \mathrm{P}=0,06)$, sangramento maior $(0,2 \%$ vs.

\footnotetext{
${ }^{1}$ Resident Physician in the Department of Invasive Cardiology of the Instituto Dante Pazzanese de Cardiologia. São Paulo, SP, Brazil.

${ }^{2} \mathrm{Ph}$.D. Chief of the Coronary Intervention Service Invasive Cardiology of the Instituto Dante Pazzanese de Cardiologia. São Paulo, SP, Brazil.

${ }^{3} \mathrm{Ph}$.D. Interventional cardiologist at the Department of Invasive Cardiology of the Instituto Dante Pazzanese de Cardiologia. São Paulo, SP, Brazil. ${ }^{4} \mathrm{Ph}$.D. Interventional cardiologist at the Department of Invasive Cardiology of the Instituto Dante Pazzanese de Cardiologia. São Paulo, SP, Brazil

${ }^{5}$ Doutor. Chefe da Seção Médica de Angioplastia Coronária do Instituto Dante Pazzanese de Cardiologia. São Paulo, SP, Brazil.

${ }^{6} \mathrm{Ph}$.D. Interventional cardiologist at the Department of Invasive Cardiology of the Instituto Dante Pazzanese de Cardiologia. São Paulo, SP, Brazil. ${ }^{7}$ Resident Physician in the Department of Invasive Cardiology of the Instituto Dante Pazzanese de Cardiologia. São Paulo, SP, Brazil.

${ }^{8}$ Resident Physician in the Department of Invasive Cardiology of the Instituto Dante Pazzanese de Cardiologia. São Paulo, SP, Brazil.

${ }^{9}$ Interventional cardiologist at the Department of Invasive Cardiology of the Instituto Dante Pazzanese de Cardiologia. São Paulo, SP, Brazil.
}

\begin{abstract}
${ }^{10} \mathrm{Ph}$.D. Interventional cardiologist at the Department of Invasive Cardiology of the Instituto Dante Pazzanese de Cardiologia. São Paulo, SP, Brazil.

${ }^{11} \mathrm{Ph} . \mathrm{D}$. Interventional cardiologist at the Department of Invasive Cardiology of the Instituto Dante Pazzanese de Cardiologia. São Paulo, SP, Brazil.

${ }^{12}$ Full professor. Director of Invasive Cardiology Service of the Instituto Dante Pazzanese de Cardiologia. São Paulo, SP, Brazil.

${ }^{13}$ Full professor. General Director of the Instituto Dante Pazzanese de Cardiologia. São Paulo, SP, Brazil.

${ }^{14}$ Full professor. Director, Center for Interventions in Structural Heart Disease of the Instituto Dante Pazzanese de Cardiologia. São Paulo, SP, Brazil
\end{abstract}

Correspondence to: Samir Duarte Ibrahim. Av. Dr. Dante Pazzanese, 500 - Vila Mariana - São Paulo, SP, Brazil - CEP 04012-180

E-mail: samirdi@yahoo.com.br

Received on: 6/12/2013 - Accepted on: 8/26/2013 
DESCRIPTORS: Angioplasty. Radial artery. Angina, stable. Acute coronary syndrome.

T he transradial approach for percutaneous coronary intervention (PCI) was originally introduced by Kiemeneij et al. ${ }^{1}$ Its benefits, including reduced complications of the puncture site, early ambulation, and diminished hospitalisation time, have been demonstrated in several trials conducted in Brazilian centers and in other countries. ${ }^{2-10}$

Among all the potential benefits of this type of access, safety is undoubtedly the most attractive. With radial access, hemorrhagic and vascular complications (bleeding, pseudoaneurysm, arteriovenous fistula, and bruising) are rare and generally easily circumvented. However, the occurrence of complications is influenced by the learning curve. ${ }^{2,10}$

The transradial approach is still not routinely used in interventional cardiology centers for diagnostic and therapeutic procedures. Globally, less than $10 \%$ of the procedures are performed by this route. ${ }^{11}$ The Registro Central Nacional de Intervenções Cardiovasculares (Central Brazilian Registry of Cardiovascular Interventions - CENIC) showed that in 2008 , only $12.6 \%$ of the procedures were performed by this technique in Brazil. ${ }^{2}$ Previous trials have shown that, in the beginning of the learning curve, technical failures and the necessity of crossover to the femoral technique are relatively frequent. ${ }^{12,13}$

Most trials evaluating the transradial approach compared to the femoral route revealed benefits in the presence of unstable coronary artery disease (CAD), especially in ST-segment elevation myocardial infarction (STEMI), because these patients have greater probability of bleeding from the access route, due to the adjunct medication used (antiplatelet, antithrombotic, thrombolytic, etc.).

The aim of this study was to evaluate the in-hospital results of PCI by transradial approach, performed in a busy tertiary hospital that has progressively incorporated this technique into daily clinical practice, comparing patients with stable and unstable CAD.

\section{METHODS}

This was a retrospective study, using the database of a consecutive series of patients with stable CAD (stable angina or silent ischemia) and unstable CAD (with or without ST-segment elevation), treated with PCI by radial approach with $6 \mathrm{~F}$ catheter at Instituto de Cardiologia Dante
$0,6 \% ; \mathrm{P}=0,09)$ ou complicação vascular ( $1 \%$ vs. $0,6 \% ; \mathrm{P}=0,47)$ foi baixa e não diferiu entre os grupos. Conclusões: ICP por via radial mostrou-se segura e eficaz, tanto em pacientes com DAC estável como instável, tratados em hospital terciário que progressivamente tem incorporado essa técnica à rotina diária.

DESCRITORES: Angioplastia. Artéria radial. Angina estável. Síndrome coronariana aguda.

Pazzanese, São Paulo, Brazil, from December of 2007 to October of 2012.

Data from hospital outcomes were entered on a standardized form, comprising clinical, angiographic, and procedural characteristics, in addition to the clinical evolution of the patient until discharge.

\section{Procedure}

Through wrist hyperextension and infiltration of 1-2 $\mathrm{mL}$ of $2 \%$ xylocaine, the radial artery was punctured 1 $\mathrm{cm}$ proximal to the radial styloid process using a needle with a polyethylene catheter (Jelco $\left.{ }^{\circledR} n^{\circ} 20-22\right)$ and using the Seldinger technique. After the puncture, a 0.021-inch guidewire was introduced, followed by a small skin incision with a scalpel blade and insertion of a $6 \mathrm{~F}$ sheath. A solution containing 5,000 IU heparin sulphate was administered through the sheath. At the end of the procedure, the sheath was immediately removed, and hemostasis was obtained with a compression band, the TR Band ${ }^{\mathrm{TM}}$ (Terumo Medical - Tokyo, Japan). A clinical examination of the puncture site and an evaluation of the radial pulse were performed at the time of hospital discharge.

\section{Definitions}

Angiographic success was defined as a reduction of the target lesion to a stenosis diameter $<30 \%$, with maintenance or restoration of the normal antegrade flow (Thrombolysis in Myocardial Infarction [TIMI] 3). ${ }^{14-16}$ Procedural success was considered when angiographic success and the absence of major clinical complications (death, nonfatal myocardial infarction $[\mathrm{MI}]$, or emergency coronary artery bypass graft [CABG] surgery) were obtained.

MI associated with the procedure was defined as the development of new $\mathrm{Q}$ waves and/or elevation of CK-MB ( $>$ three times the baseline level).

Vascular complications were defined as presence of hematoma $>10 \mathrm{~cm}$ at the site of arterial puncture; major bleeding, characterized as a fall in hemoglobin $>3 \mathrm{~g} / \mathrm{dL}$ or a need for red blood cells transfusion; or a need for surgical correction of complications (hematoma, pseudoaneurysm, or arteriovenous fistula formation). 


\section{Statistical analysis}

The SPSS for Windows was used for statistical analysis. Qualitative variables were presented as absolute and relative frequencies, and compared with the chi-squared or Fisher's exact test. Quantitative variables were described as means and standard deviations. To test the groups, the Kolmogorov-Smirnov test was used to check the normality of the data. When the distribution was normal, Student's $t$-test was used. Otherwise, the Wilcoxon test was used. The level of significance was set at $5 \%$.

\section{RESULTS}

During the study period, from December of 2007 to October of 2012, 2,507 consecutive patients were treated with PCI by transradial approach with $6 \mathrm{~F}$ catheter; 1,821 (72.6\%) had a clinical diagnosis of stable CAD, and 686 (27.4\%) of unstable CAD.

In the present service, there was a progressive increase in the use of the transradial approach for performing PCI until 2010, stabiliszing in 2010 and 2011, and surpassing the femoral approach by $2012(11.8 \%$ in $2008,26.1 \%$ in $2009,45.1 \%$ in $2010,42.6 \%$ in 2011 , and $55 \%$ in 2012) (Figure 1).

Patients with stable disease had a more complex clinical profile, characterized by older age, female gender, and higher incidence of comorbidities such as diabetes, systemic hypertension, dyslipidaemia, chronic renal failure, previous $\mathrm{MI}$, and previous $\mathrm{CABG}$, when compared with those of the group with unstable CAD (Table 1).

Regarding angiographic characteristics, most analyzed variables showed no differences between groups. Approximately one-third of the population had involvement of two or three vessels, and the left anterior descending artery was the most frequently treated vessel. The characteristics of the procedure also showed no differences in the diameter

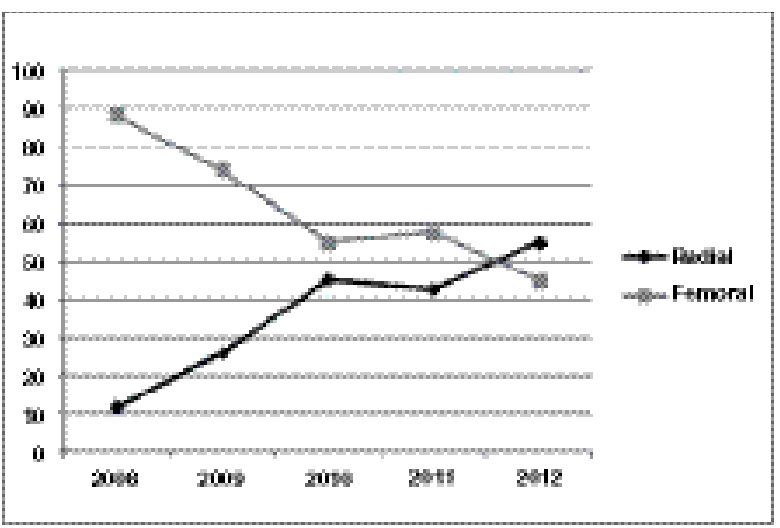

Figure - Percentage of use of radial and femoral techniques from 2008 to 2012. and length of the stent used. The use of glycoprotein IIb/ IIIa inhibitors was sparse, and was more frequent in the unstable CAD group (Table 2).

The in-hospital outcomes are shown in Table 3. The success rate was high in both groups, but higher among patients with stable CAD $(94.6 \%$ vs. $92.4 \% ; \mathrm{P}=0.05)$. The death rate was low and did not differ between groups $(0.2 \%$ vs. $0.3 \% ; \mathrm{P}=0.61)$, as did rates of periprocedural MI $(4.7 \%$ vs. $6.6 \%$; $\mathrm{P}=0.07)$, stroke $(0.1 \%$ vs. $0.1 \%$; $\mathrm{P}$ $>0.99)$, PCI $(0.1 \%$ vs. $0.3 \%, \mathrm{P}=0.30), \mathrm{CABG}(0.4 \%$ vs $0 \% ; \mathrm{P}=0.06)$, major bleeding $(0.2 \%$ vs. $0.6 \% ; \mathrm{P}=0.09)$, or vascular complications $(1 \%$ vs. $0.6 \% ; \mathrm{P}=0.47)$. There was a lower incidence of nephropathy induced by contrast in the stable CAD group $(2.1 \%$ vs. $4.1 \% ; \mathrm{P}=0.01)$, whereas in the unstable CAD group a greater number of ad hoc interventions occurred, which justifies the higher volume of contrast in this group.

The hospital stay was significantly lower in the group with stable CAD $(1.6 \pm 9.1$ days vs. $4.9 \pm 42.7$ days; $P$ $<0.01) .73 \%$ of all patients were discharged the next day after the procedure.

\section{DISCUSSION}

The main finding of the present study was that the transradial approach used in clinical practice in a tertiary hospital is safe and effective, both in patients with stable $\mathrm{CAD}$ and with unstable CAD. This access point minimizes

TABLE 1

Demographic and clinical characteristics

\begin{tabular}{lccc}
\hline & $\begin{array}{c}\text { Stable CAD Unstable CAD } \\
(\mathbf{n}=\mathbf{1 , 8 2 1})\end{array}$ & $(\mathbf{n}=\mathbf{6 8 6})$ & $\mathbf{P}$ \\
\hline Age, mean & $61.3 \pm 10.0$ & $59.1 \pm 10.7$ & $<0.01$ \\
Females, \% & 26 & 20.8 & $<0.01$ \\
Diabetes mellitus, \% & 34.3 & 24.1 & $<0.01$ \\
Hypertension, \% & 87.9 & 81.8 & $<0.01$ \\
Dyslipidaemia, \% & 72.1 & 59.2 & $<0.01$ \\
Smoking, \% & 17.7 & 27.8 & $<0.01$ \\
COPD, \% & 2.7 & 1.9 & 0.31 \\
Chronic renal failure, \% & 24.2 & 18.5 & $<0.01$ \\
Prior myocardial & 41.2 & 31.8 & $<0.01$ \\
infarction, \% & & & \\
Previous PCI, \% & 11.8 & 11.5 & 0.88 \\
Previous CABG, \% & 6.2 & 3.6 & 0.01 \\
Prior stroke, \% & 1.4 & 1.6 & 0.71 \\
\hline
\end{tabular}

$\mathrm{CAD}=$ coronary artery disease $; \mathrm{COPD}=$ chronic obstructive pulmonary disease; $\mathrm{PCI}=$ percutaneous coronary intervention; $\mathrm{CABG}=$ coronary artery bypass grafting. 
TABLE 2

Angiographic and procedural characteristics

\begin{tabular}{lccc}
\hline & $\begin{array}{c}\text { Stable CAD } \\
(\mathbf{n}=\mathbf{1 , 8 2 1})\end{array}$ & $\begin{array}{c}\text { Unstable CAD } \\
(\mathbf{n}=\mathbf{6 8 6})\end{array}$ & $\mathbf{P}$ \\
\hline Extent of disease, \% & & & 0.26 \\
One vessel & 64.7 & 66.4 & \\
Two vessels & 29.9 & 27 & \\
Three vessels & 5.3 & 6.6 & \\
Treated vessel, \% & & & \\
LAD & 38.9 & 41.4 & \\
LCx & 26.8 & 17.3 & \\
RC & 33.6 & 40.7 & \\
LMCA & 0.78 & 0.64 & 0.80 \\
Saphenous graft, \% & 0.8 & 1.6 & 0.13 \\
Bifurcation lesion, \% & 16.8 & 14.3 & 0.06 \\
Stent diameter, mm & $3.03 \pm 0.42$ & $3.08 \pm 0.42$ & 0.75 \\
Stent length, mm & $20.7 \pm 6.8$ & $20.5 \pm 6.4$ & 0.01 \\
GPI IIb/IIIa, \% & 1 & $147.5 \pm 48.9$ & $<.7$ \\
Contrast volume, mL & $81.4 \pm 38.3$ & & \\
\hline
\end{tabular}

$\mathrm{CAD}=$ coronary artery disease $; \mathrm{LAD}=$ left anterior descending, LCx $=$ left circumflex artery; $\mathrm{RC}=$ right coronary artery; LMCA $=$ left main coronary artery; GPI = glycoprotein receptor inhibitor.

TABLE 3

In-hospital outcomes

\begin{tabular}{lccc}
\hline & $\begin{array}{c}\text { Stable CAD } \\
(\mathbf{n}=\mathbf{1 , 8 2 1})\end{array}$ & $\begin{array}{c}\text { Unstable CAD } \\
(\mathbf{n}=\mathbf{6 8 6})\end{array}$ & $\mathbf{P}$ \\
\hline Clinical success, \% & 94.6 & 92.4 & 0.05 \\
Death, \% & 0.2 & 0.3 & 0.61 \\
Myocardial & 4.7 & 6.6 & 0.07 \\
infarction, \% & & 0.1 & $>0.99$ \\
Stroke, \% & 0.1 & 0.3 & 0.30 \\
New PCI, \% & 0.1 & 0.4 & 0.06 \\
CABG, \% & 0 & 0.6 & 0.09 \\
Major bleeding, \% & 0.2 & 0.6 & 0.47 \\
Vascular & 1 & 4.1 & 0.01 \\
complications, \% & & $4.9 \pm 42.7$ & $<0.01$ \\
Renal failure, \% & 2.1 & & \\
Length of stay, days & $1.6 \pm 9.1$ & & \\
\hline CAD = coronary artery disease; PCI = percutaneous coronary \\
intervention; CABG = coronary artery bypass grafting.
\end{tabular}

the risk of bleeding and vascular complications, equalising such different populations, despite the adjunctive medication used.

The transradial approach is associated with a dramatic reduction in the risk of complications of the approach route when compared to the transfemoral route. Growing evidence in several trials demonstrate a significant reduction in major adverse cardiovascular events when the transradial approach is used, mainly in the STEMI scenario. ${ }^{17}$ The transradial approach is particularly attractive in primary PCI, when this technique is performed by experienced surgeons, since these patients are treated with a more aggressive antiplatelet and antithrombotic regimen, resulting in a reduction of bleeding complications and, subsequently, of major adverse cardiovascular events.

Specifically in the treatment of unstable CAD, Romagnoli et al. ${ }^{18}$ demonstrated that, in 30 days, the use of the radial access reduced the cardiovascular death, incidence of bleeding, and length of hospital stay, findings similar to those observed in a meta-analysis involving 21 trials and 8,534 patients. ${ }^{19}$ The analysis of the same population, in the RIVAL trial, also demonstrated benefit in reducing the mortality, but this finding was limited to the subgroup with ST-segment elevation. ${ }^{17}$

This study also showed a reduced incidence of bleeding and vascular complications related to the radial route, as was previously demonstrated in a number of trials published recently. ${ }^{5,6,17}$

In this study of a real-world population, it was shown that the choice of the radial access for PCI still is less used than the femoral access, but now accounts for nearly half of all interventions at this institution, reflecting the progressive incorporation of the knowledge acquired with the method.

\section{Limitations of the study}

This was a retrospective, observational, single-center study, with all the limitations inherent in this type of study, in which the decision with respect to the approach used was responsibility of the surgeon, based on the experience acquired, clinical profile of the patient, and vascular condition of the site. However, for the same reasons, this may have been the best way to reproduce the daily practice of a coronary intervention laboratory.

\section{CONCLUSIONS}

The use of percutaneous coronary intervention by transradial approach was safe and effective, both in patients with stable and unstable coronary artery disease treated at a tertiary care hospital that has progressively incorporated this technique into daily clinical practice. This entry point minimized the risk of bleeding and vascular complications, equalising such distinct populations, regardless of the adjunctive medication used.

\section{CONFLICTS OF INTEREST}

The authors declare no conflicts of interest. 
1. Kiemeneij F, Laarman GJ, de Melker E. Transradial artery coronary angioplasty. Am Heart J. 1995;129(1):1-7.

2. Agostoni P, Biondi-Zoccai GG, de Benedictis ML, Rigattieri S, Turri M, Anselmi M, et al. Radial versus femoral approach for percutaneous coronary diagnostic and interventional procedures; systematic overview and meta-analysis of randomized trials. J Am Coll Cardiol. 2004;44(2):349-56.

3. Andrade PB, Tebet MA, Andrade MV, Labrunie A, Mattos LA. Radial approach in percutaneous coronary interventions: current status in Brazil. Arq Bras Cardiol. 2011;96(4):312-6.

4. Boechat e Salles JA, Andrea JCM, Cortes LA, Carestiano LV, Santos LFC, Figueira HR. Análise comparativa de segurança e eficácia entre as vias de acesso radial e femoral na realização de intervenção coronária percutânea no infarto agudo do miocárdio. Rev Bras Cardiol Invasiva. 2009;17(4):498-504.

5. Jolly SS, Amlani S, Hamon M, Yusuf S, Mehta SR. Radial versus femoral access for coronary angiography or intervention and the impact on major bleeding and ischemic events: a systematic review and meta-analysis of randomized trials. Am Heart J. 2009;157(1):13240 .

6. Rao SV, Ou FS, Wang TY, Roe MT, Brindis R, Rumsfeld JS, et al. Trends in the prevalence and outcomes of radial and femoral approaches to percutaneous coronary intervention: a report from the National Cardiovascular Data Registry. JACC Cardiovasc Interv. 2008;1(4):379-86.

7. Dall'Orto CC, Lapa GA, Carneiro Neto JD, Carnieto NM, Oliveira Neto JB, Mauro MFZ, et al. Angioplastia coronária nas indicações Off-Label: comparação das vias radial vs. femoral. Rev Bras Cardiol Invasiva. 2010;18(2):177-84.

8. Hamon M, Mehta S, Steg PG, Faxon D, Kerkar P, Rupprecht HJ, et al. Impact of transradial and transfemoral coronary interventions on bleeding and net adverse clinical events in acute coronary syndromes. EuroIntervention. 2011;7(1):91-7.

9. Kiemeneij F, Laarman GJ. Transradial artery Palmaz-Schatz coronary stent implantation: results of a single-center feasibility study. Am Heart J. 1995;130(1):14-21.

10. Kiemeneij F, Laarman GJ, Odekerken D, Slagboom T, van der Wieken R. A randomized comparison of percutaneous transluminal coronary angioplasty by the radial, brachial and femoral approaches: the access study. J Am Coll Cardiol. 1997;29(6):1269-75.

11. Chase AJ, Fretz EB, Warburton WP, Klinke WP, Carere RG, Pi D, et al. Association of the arterial access site at angioplasty with transfusion and mortality: the M.O.R.T.A.L study (Mortality benefit Of Reduced Transfusion after percutaneous coronary intervention via the Arm or Leg). Heart. 2008;94(8):1019-25.
12. Rao SV, Cohen MG, Kandzari DE, Bertrand OF, Gilchrist IC The transradial approach to percutaneous coronary intervention: historical perspective, current concepts, and future directions. J Am Coll Cardiol. 2010;55(20):2187-95.

13. Nunes GL, Oliveira AT, Alves L, Alfonso T. Influência da curva de aprendizado no sucesso e na ocorrência de complicações associadas aos procedimentos pela via radial. Rev Bras Cardiol Invasiva. 2007;15(2):115-8.

14. Guimarães JI, Sousa JE, Ribeiro E, Mattos LA, Sousa AGMR, Nunes G, et al. Diretriz de indicações e utilizações das intervenções percutâneas e stent intracoronariano na prática clínica. Arq Bras Cardiol. 2003;80(Supl 1):1-14.

15. Smith SC Jr, Feldman TE, Hirshfeld JW Jr, Jacobs AK, Kern MJ King SB 3rd, et al. American College of Cardiology/American Heart Association Task Force on Practice Guidelines; ACC/AHA/SCAI Writing Committee to Update 2001 Guidelines for Percutaneous Coronary Intervention. ACC/AHA/SCAI 2005 guideline update for percutaneous coronary intervention: a report of the American College of Cardiology/American Heart Association Task Force on Practice Guidelines (ACC/AHA/SCAI Writing Committee to Update 2001 Guidelines for Percutaneous Coronary Intervention). Circulation. 2006;113(7):e166-286.

16. TIMI Study Group. The Thrombolysis in Myocardial Infarction (TIMI) trial. Phase-I findings. N Engl J Med. 1985;312(14):932-6. 17. Jolly SS, Yusuf S, Cairns J, Niemelä K, Xavier D, Widimsky $\mathrm{P}$, et al. Radial versus femoral access for coronary angiography and intervention in patients with acute coronary syndromes (RIVAL): a randomised, parallel group, multicentre trial. Lancet. 2011;377(9775):1409-20.

18. Romagnoli E, Biondi-Zoccai G, Sciahbasi A, Politi L, Rigattieri S, Pendenza G, et al. Radial versus femoral randomized investigation in ST-Segment Elevation acute coronary syndrome: the RIFLESTEACS (Radial Versus Femoral Randomized Investigation in ST-Elevation Acute Coronary Syndrome) Study. J Am Coll Cardiol. 2012;60(24):2481-9.

19. Mehta SR, Jolly SS, Cairns J, Niemela K, Rao SV, Cheema AN, et al. Effects of radial versus femoral artery access in patients with acute coronary syndromes with or without ST-Segment Elevation J Am Coll Cardiol. 2012;60(24):2490-9. 